\title{
CORRECTION OF THE ARC ARRAY EXCITATION USING GENETIC ALGORITHM
}

\author{
R.S. Al'metov, ruslannss@mail.ru, \\ A.B. Khashimov, xab@kipr.susu.ac.ru \\ South Ural State University, Chelyabinsk, Russian Federation
}

\begin{abstract}
The method of correction the discrete phase distribution of the circular arc phased array for alignment of bearing directions of the navigation radio beacons is proposed. Switchboarding stepscanning pattern of the arc array is accompanied by subscanning for given minimal discrete scan angle.

The exact technique to determine the amplitude and phase distributions for the arc array excitation is proposed. This technique include both the mutual coupling of the array radiators and influence of the current distribution on cylindrical surface, over array is located. Numerical method for reducing size of the system of linear algebraic equiations is developed. This system due to corresponding summarize-integral equiations.

It is shown that discretization of finding phase distribution (amplitude distribution is fixed) leads to inaccurate bearing directions of navigation radio beacons. For correcting the phase distribution is used the genetic algorithm, which has some advantages over traditional techniques of optimization. The results of modeling the subscanning mode shows practical utility and efficiency of the proposed correcting technique.
\end{abstract}

Keywords: arc phased array, summarize-integral equiations, discrete phase distribution, correcting genetic algorithm.

The circular arc phased arrays as part of cylindrical arrays widely used for navigation radio beacons. This is due to the possibility of wide-angle scanning $\left(360^{\circ}\right)$ of the summary and difference patterns, which has practically permanent shapes on azimuth plane. The arc array differs from linear and plane array the lesser level of mutual coupling between array radiators. In this case the axes of the radiators located above cylindrical surface mutually unfolded from each other.

The general scanning mode for arc array is switching moving (step-scanning) of the fixed arc array (fixed number of the radiators and fixed amplitude and phase distribution) on the cylinder perimeter for given discrete scan angle $\Delta \alpha_{1}$, which equal the angle interval between radiators. More accurate subscanning mode for angle discrete $\Delta \alpha_{2}=\Delta \alpha_{1} / n$, where $n$ is an integer, is made for fixed arc array due to using digitally controlled discrete phase shifters. An amplitude distribution also is fixed.

Such subscanning mode necessary to implement with minimal distortions for given angle sector $\Delta \alpha_{1}$. In fact, minimal phase discrete $\Delta \Phi$ limits the accuracy of the bearing direction of difference pattern and direction of the maximum for summarize pattern. The arc array far-field pattern can be approximated by [1]:

$$
F(\varphi)=\sum_{n=1}^{N} I_{n, 0} f_{\text {rad }}\left(\varphi-\varphi_{n}\right) \exp \left\{i\left[k R_{c} \cos \left(\varphi-\varphi_{n}\right)-\psi_{n, 0}\right]\right\}
$$

where $N$ is an integer number of the radiators; $I_{n, 0}, \psi_{n, 0}$ is amplitude and phase of the $n$-th radiator; $k=2 \pi / \lambda$ is wave number of the medium; $\lambda$ is wavelength of the electromagnetic field; $R_{c}$ is radius of the circular array. The pattern of radiator in Eq. (1) often define as ideal pattern of the single radiator, located above the infinity perfectly conducting plane screen, that is: $f_{\text {rad }}\left(\varphi-\varphi_{n}\right)=\cos \left(\varphi-\varphi_{n}\right)$.

To improve the accuracy of alignment phase distribution for subscanning mode we use exact electromagnetic equations. These equations are used to determine both the mutual coupling of the array radiators and influence of the current distribution on cylindrical surface.

For the array radiators as the vertical dipoles are located above an extensive cylindrical surface we use an asymptotic correspondence of 3D vector and 2D scalar electromagnetic problems [2]. Thus, we 


\section{Краткие сообщения}

have the filaments of electrical currents as 2D radiators are located at the dipoles coordinates and parallel them. The amplitude and phase distribution these dipoles are equal to $I_{n, 0}, \psi_{n, 0}, n=\overline{1: N}$, the limit radius of the filaments is $a<<\lambda$. Assuming a perfectly conducting cylindrical surface, the boundary conditions for the tangential components of the total electric field leads to system of the summarizeintegral equations:

$$
\begin{aligned}
& \int_{L_{c}} j_{s} H_{0}^{(2)}\left(k r_{p q}\right) d l_{q}+\sum_{n=1}^{N} I_{n, 1} H_{0}^{(2)}\left(k r_{p q}\right)=-\sum_{n=1}^{N} I_{n, 0} H_{0}^{(2)}\left(k r_{p q}\right) ; p \in L_{c} ; \\
& \int_{L_{c}} j_{s} H_{0}^{(2)}\left(k r_{p q}\right) d l_{q}+I_{m, 1} H_{0}^{(2)}(k a)+\sum_{n \neq m}^{N} I_{n, 1} H_{0}^{(2)}\left(k r_{p q}\right)=0 ; p \in p_{m} ; m=\overline{1: N,}
\end{aligned}
$$

where $I_{n, 1}$ is the current induced on $n$-th array's radiator; $I_{n, 0}$ is an excitation current; $j_{s}$ is the current on the contour $L_{c}$ as the section of cylindrical surface, formed by perpendicular plane to the axis $z$.

Thus, the total pattern of the arc array as solution of exact Eq. (2) defined by:

$$
E_{z}(\varphi)=\sum_{n=1}^{N}\left(I_{n, 0}+I_{n, 1}\right) H_{0}^{(2)}\left(k r_{p q}\right)+\int_{L_{c}} j_{s} H_{0}^{(2)}\left(k r_{p q}\right) d l_{q},
$$

we assume that axis $z$ is parallel to the filaments.

The serious problem for numerical solution of the Eq. (2) is large size of the discrete form as system of the linear algebraic equations, especially for large dimensions of cylinder contour. We use the numerical approach for decreasing such size as two stage procedure. First: we solve the Eq. (2) for given $L_{c}$ that has large, but limited $R_{c}$, acceptable for using computer recourses. Second: we introduce new limited arc $L_{a}$ to substitute for contour $L_{c}$. Then we obtain numerical solution of the Eq. (2) for given arc $L_{a}$. Comparing of two patterns from Eq. (3) for these cases shows that limited arc $L_{a}$ for angle $130^{\circ}$ is perfectly enough for practically using accuracy. Fig. 1 depicts comparing exact pattern for contour $L_{c}$, exact pattern for arc $L_{a}$ and approximate pattern from Eq. (1). In this case $\lambda=0.32 \mathrm{~m}, R_{c}=2.2 \mathrm{~m}$, and optimal amplitude and phase distribution $I_{n, 0}$. We use projective method of the collocations for numerical solution of the Eq. (2), using high-accuracy Gauss quadrature formulas.

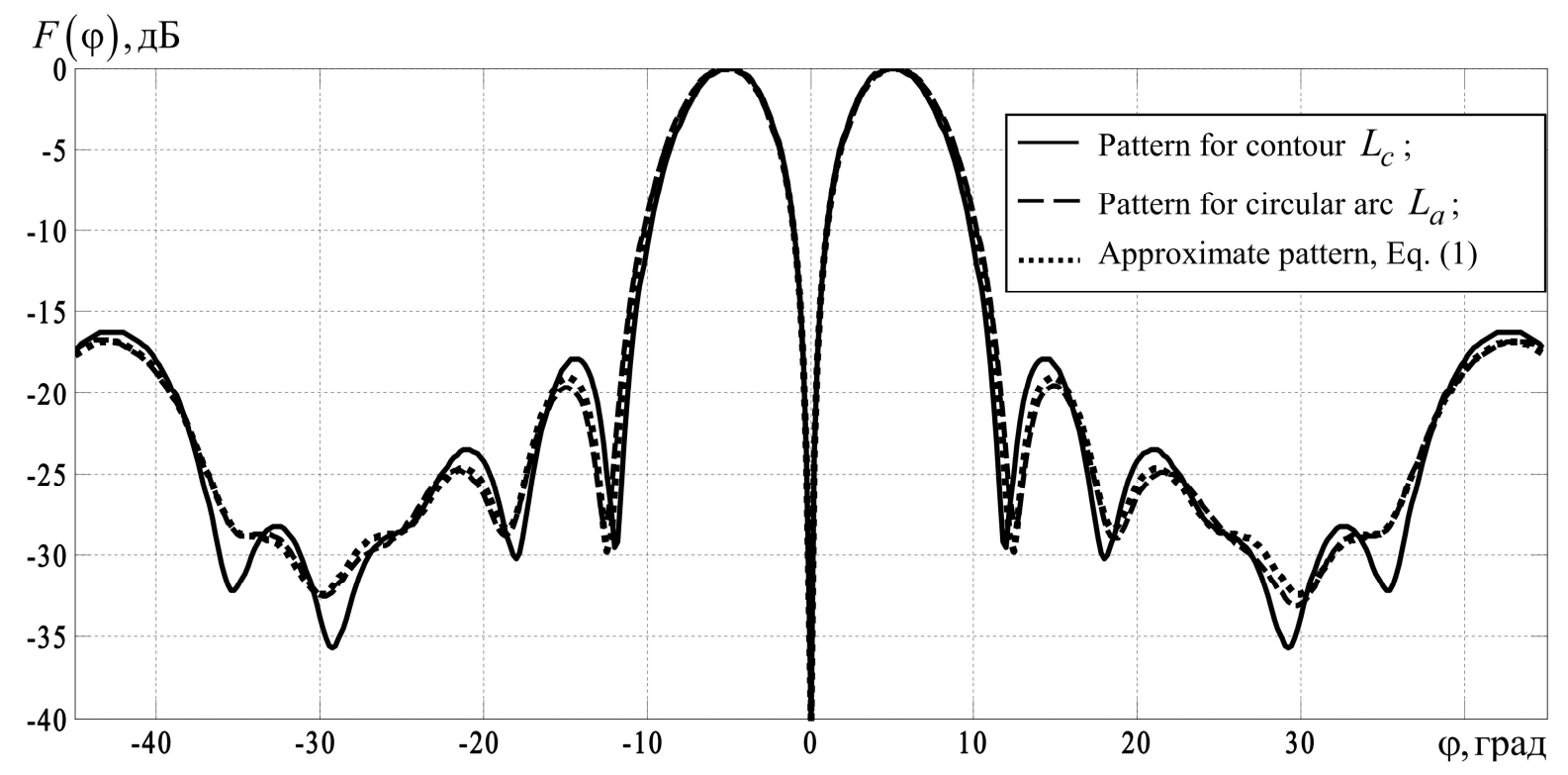

Fig. 1. Difference patterns of the circular arc array in azimuth plane 
Thus, using limited arc $L_{a}$ as part of the contour $L_{c}$ can reduce time computation of the Eq. (2) almost three times with sufficient accuracy of results. High-speed computations and reducing of the computer recourses is necessary to use effective optimization techniques for synthesis of an arc array patterns.

We consider some examples of synthesis the correct phase distributions for given subscanning mode is including angle sector $\pm 2.5^{\circ}$ and step-scan $0.5^{\circ}$ for fixed arc array. For comparison we use wide-known quasi-Newton technique [4] and actively developing genetic algorithm [5].

Genetic algorithm includes the following steps.

1. Creating the set of genotypes of the initial population - it means creating the set of random vectors of phase distribution $\psi_{n, 0}^{p}, p=\overline{1, q}$, these vectors are divisible to minimal phase discrete $\Delta \Phi=11.25^{\circ}, q$ is dimension of the set.

2. Evaluation of the genotypes set using adaptation function, it means defining of the aim functions $\Psi_{p}\left(\psi_{n, 0}^{p}\right), p=\overline{1, q}$.

3. Selection of the most adapted population, which correspond to the minimal value of the aim function.

4. Check of the convergence criterions (the number of iterations, no decrease the values of the best aim function for some step by step iterations). Then, if at least one of the criterions is done, it necessary to remember the best vector, else go to 5 .

5. Mutation, it means adding some random numbers vector $d$ to all components of vector $\psi_{n, 0}$. This vector correspond to minimal value of the aim function. Besides, random numbers are divisible to minimal phase discrete $\Delta \Phi$. The purpose of such mutation is creating new vector set, rather adaptive for optimization criterions.

6. Go to 2 .

Fig. 2 depicts the result of the synthesis the correct phase distributions for two patterns of the arc array, these patterns are correspond subscane mode angles $\varphi_{1}=-2.5^{\circ}$ and $\varphi_{2}=2.5^{\circ}$.

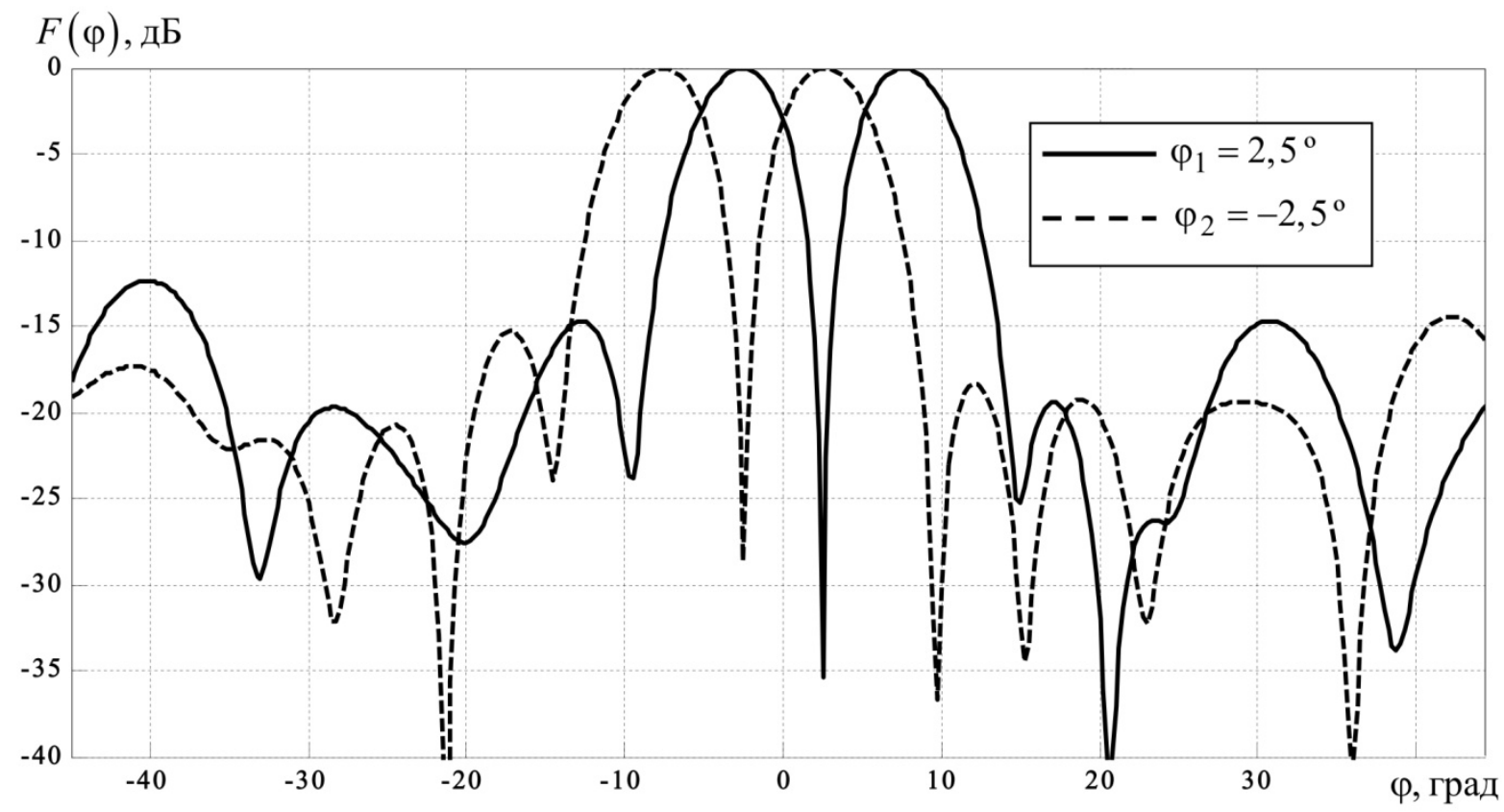

Fig. 2. Difference patterns of the circular arc array in subscane mode

Evaluation of the bearing direction accuracy shows that azimuth errors does not exceed the value $0.23 \%$ for all the set of subscane mode given directions. In terms of the bearing direction accuracy the genetic algorithm and the quasi-Newton method give out almost identical results. However, the ge- 


\title{
Краткие сообщения
}

netic algorithm is based on variation of the random vectors, therefore the computation time is variable and it can be obtained as average time for computation the set of given iterations. Then, comparison of these synthesis approaches shows, that using the quasi-Newton method requires more then $1.53 \mathrm{compu}-$ tation time to obtain similar results.

Thus, the genetic algorithm has some numerical advantages over other practically used optimization techniques, especially for large-scale problems. The defects of the genetic algorithm are fuzzy criterions for optimization procedure return, considerable dependence of the solution stability and convergence on size the random vectors.

\footnotetext{
References

1. Hansen R.C. Phased Array Antennas. J. Wiley \& Sons, 2009, 560 p. DOI: 10.1002/9780470529188

2. Voitovich N.I., Khashimov A.B. On the Correspondence of Asymptotic Solutions to 2D and 3D Problems in Antenna Engineering. Journal of Communications Technology and Electronics, 2010, vol. 55, no. 12, pp. 1374-1379. DOI: 10.1134/S1064226910120077

3. Khashimov A.B., Salikhov R.R., Al'metov R.S. [Using of High Precision Numerical Techniques for Antenna System Design]. Bulletin of the South Ural State University. Computational Mathematics and Software Engineering, 2014, vol. 3, no. 2, pp. 77-91. (in Russ.)

4. Coleman T.F., Li Y. On the Convergence of Reflective Newton Methods for Large-Scale Nonlinear Minimization Subject to Bounds. Mathematical Programming, 1994, vol. 67, no. 2, pp. 189-224. DOI: $10.1007 / \mathrm{BF} 01582221$

5. Melanie M. An Introduction to Genetic Algorithms. Massachusetts, MIT Press Cambridge, 1996, pp. 87-117.
}

Received 20 May 2016

\section{КОРРЕКЦИЯ ВОЗБУЖДЕНИЯ ДУГОВОЙ АНТЕННОЙ РЕШЕТКИ С ИСПОЛЬЗОВАНИЕМ ГЕНЕТИЧЕСКОГО АЛГОРИТМА}

\author{
Р.С. Альметов, А.Б. Хашимов \\ Южно-Уральский государственный университет, г. Челябинск
}

\begin{abstract}
Предложен метод коррекции дискретного фазового распределения дуговой фазированной антенной решетки для повышения точности пеленгационных характеристик. Коммутационное перемещение диаграммы направленности дуговой фазированной антенной решетки сопровождается подсканированием с заданным минимальным дискретом сканирования. Предложен строгий метод расчета амплитудно-фазовых распределений возбуждения дуговых фазированных антенных решеток, учитывающий как взаимное влияние излучателей, так и влияние распределения токов на цилиндрической поверхности, над которой расположена решетка.

Разработан численный метод уменьшения размерности системы линейных алгебраических уравнений, к которым приводят сумматорно-интегральные уравнения. Показано, что дискретизация расчетного фазового распределения для фиксированного амплитудного распределения приводит к неточному воспроизведению пеленгационных характеристик азимутально-дальномерных радиомаяков.

Для коррекции фазового распределения использован генетический алгоритм, обладающий определенными преимуществами перед традиционными методами оптимизации. Приведены результаты математического моделирования режима подсканирования, показывающие эффективность и практическую применимость предложенного метода коррекции.

Ключевые слова: дуговая фазированная антенная решетка, сумматорно-интегральные уравнения, дискретное фазовое распределение, генетический алгоритм коррекиии.
\end{abstract}




\section{Лumepamypa}

1. Hansen, R.C. Phased Array Antennas / R.C. Hansen. - Second Edition. - J. Wiley \& Sons.2009. - 560 p. DOI: 10.1002/9780470529188

2. Voitovich, N.I. On the Correspondence of Asymptotic Solutions to $2 D$ and $3 D$ Problems in Antenna Engineering / N.I. Voitovich , A.B. Khashimov // Journal of Communications Technology and Electronics. - 2010. - Vol. 55, No. 12. - P. 1374-1379. DOI: 10.1134/S1064226910120077

3. Хашимов, А.Б. Применение вычислительных схем повышенной точности в проектировании антенных систем / А.Б. Хашимов, Р.Р. Салихов, Р.С. Альметов // Вестник Южно-Уральского университета. Сер. «Вычислительная математика и информатика». - 2014. - T. 3, № 2. C. 77-91.

4. Coleman, T.F. On the Convergence of Reflective Newton Methods for Large-Scale Nonlinear Minimization Subject to Bounds / T.F. Coleman and Y. Li // Mathematical Programming. - 1994. Vol. 67, no. 2. - P. 189-224. DOI: 10.1007/BF01582221

5. Melanie, M. An Introduction to Genetic Algorithms / M. Melanie. - Massachusetts: MIT Press Cambridge, 1996. - P. 87-117.

Альметов Руслан Салаватович, студент-магистрант кафедры конструирования и производства радиоаппаратуры, Южно-Уральский государственный университет, г. Челябинск; ruslannss@mail.ru.

Хашимов Амур Бариевич, канд. физ.-мат. наук, доцент кафедры конструирования и производства радиоаппаратуры, Южно-Уральский государственный университет, г. Челябинск; xab@kipr.susu.ac.ru.

Поступила в редакцию 20 мая 2016 г.

\section{ОБРАЗЕЦ ЦИТИРОВАНИЯ}

Al'metov, R.S. Correction of the Arc Array Excitation Using Genetic Algorithm / R.S. Al'metov, A.B. Khashimov // Вестник ЮУрГУ. Серия «Компьютерные технологии, управление, радиоэлектроника». - 2016. T. 16, № 4. - C. 127-131. DOI: 10.14529/ctcr160414

\section{FOR CITATION}

Al'metov R.S., Khashimov A.B. Correction of the Arc Array Excitation Using Genetic Algorithm. Bulletin of the South Ural State University. Ser. Computer Technologies, Automatic Control, Radio Electronics, 2016, vol. 16, no. 4, pp. 127-131. DOI: $10.14529 /$ ctcr 160414 